\title{
Grafted eggplant yield, quality and growth in infested soil with Verticillium dahliae and Meloidogyne incognita
}

\author{
Sebahattin Çürük(1), H. Yıldız Dasgan (2), Sedat Mansuroğlu ${ }^{(1)}$, Şener Kurt(3), \\ Meltem Mazmanoğlu ${ }^{(2)}$, Özgür Antaklı ${ }^{(1)}$ and Gülcan Tarla(4)
}

\begin{abstract}
(1)Mustafa Kemal University, Faculty of Agriculture, Department of Horticulture, 31034 Antakya-Hatay, Turkey. E-mail: sebahattincuruk@gmail.com, semansoft@hotmail.com, o_antakli@mynet.com (2)Çukurova University, Faculty of Agriculture, Department of Horticulture, Balcalı, 01330 Adana, Turkey. E-mail: dasgan@cu.edu.tr, melmazman@hotmail.com ${ }^{(3)}$ Mustafa Kemal University, Faculty of Agriculture, Department of Plant Protection, 31034 Antakya-Hatay, Turkey. E-mail: kurt@mku.edu.tr ${ }^{(4)}$ Uşak University, Eşme Technical Vocational School of Higher Education, Department of Organic Farming, Uşak, Turkey. E-mail: gulcan.tarla@usak.edu.tr
\end{abstract}

\begin{abstract}
The objective of this work was to evaluate the effect of grafting (onto Solanum torvum Sw.) on plant growth, yield and fruit quality of the Pala and Faselis eggplant (Solanum melongena L.) cultivars, grown in a soil infested with Verticillium dahliae Kleb. and Meloidogyne incognita, or in noninfested soil. Soil infestation decreased yield, plant height, final above-ground biomass, and also reduced fruit mean weight and shoot dry weight depending on cultivar or grafting. Grafting decreased fruit oxalic acid and the soluble solid contents, and increased mean fruit weight, depending on cultivar and soil infestation. Grafting also reduced the negative effects of the pathogens on disease index, plant height and shoot dry weight. Cultivar Pala was more vigorous than Faselis, and S. torvum was a vigorous rootstock. The combination of a vigorous rootstock with a weak cultivar (Faselis) is more profitable than that of a vigorous rootstock and a vigorous cultivar (Pala). Using S. torvum as a rootstock for cultivar Faselis, grown in soil infested with the pathogens, is most likely to be useful in conventional and low-input sustainable horticulture, since grafting increases protection against the pathogens, and reduces the losses in quality and yield.
\end{abstract}

Index terms: Solanum melongena, Solanun torvum, eggplant, rootstock, soil pathogens.

\section{Produção, qualidade e crescimento de beringela enxertada, em solo infestado com Verticillium dahliae e Meloidogyne incognita}

\begin{abstract}
Resumo - O objetivo deste trabalho foi avaliar o efeito sobre a altura de planta, a produção e a qualidade de frutos do enxerto das cultivares de beringela (Solanum melongena L.) Pala e Faselis em Solanum torvum Sw., quando cultivadas em solo infestado com Verticillium dahliae e Meloidogyne incognita ou em solo não infestado. A infestação do solo reduziu a produção, altura da planta, biomassa da parte aérea, massa média dos frutos, massa de matéria seca da parte aérea, conforme a cultivar utilizada e a enxertia. A enxertia reduziu os conteúdos de ácido oxálico e de sólidos solúveis e aumentou a massa média de frutos, conforme a cultivar ou a presença do patógeno no solo. A enxertia também reduziu o efeito negativo dos patógenos sobre o índice de doença, a altura de planta e a massa de matéria seca da parte aérea. A cultivar Pala foi mais vigorosa que a Faselis, e $S$. torvum foi um porta-enxerto vigoroso. A combinação de porta-enxerto vigoroso com a cultivar fraca (Faselis) foi mais adequada que a de porta-enxerto vigoroso e a cultivar vigorosa (Pala). O uso de $S$. torvum como porta-enxerto para a cultivar Faselis, em solo infestado, é provavelmente promissora na horticultura convencional e na horticultura sustentável de baixos insumos, pois a enxertia aumenta a proteção contra os patógenos, e reduz a perda de qualidade dos frutos e da produção.
\end{abstract}

Termos para indexação: Solanum melongena, Solanun torvum, berinjela, porta-enxerto, patógenos do solo.

\section{Introduction}

In Turkey, eggplant (Solanum melongena L.) is one of the most popular vegetables both in the summer and in the winter (protected cultivation accounts for $20 \%$ of total eggplant production). It is susceptible to numerous diseases and parasites, particularly the bacterial wilt,
Fusarium and Verticillium wilts, nematodes and insects (Collonnier et al., 2001). Soil-borne pathogens and pests such as Verticillium, Fusarium and Meloidogyne spp. may cause yield losses of up to $78 \%$ in production areas infested with Verticillium wilt (Bletsos et al., 2003). Difficulties in chemical control of these diseases, absence of crop rotation and sexual barriers 
between eggplant and its wild relatives indicate that the only short-term practical solution of the problem is the growing of susceptible eggplant cultivars, grafted on rootstocks with multiple pathogen resistance (Collonnier et al., 2001; Bletsos et al., 2003).

Vegetable production by grafting on resistant rootstocks has become a common practice to control soil-borne pathogens, especially for the cultivation of cucumber, melon, watermelon, tomato, pepper and eggplant in greenhouses in Japan, Korea, China and some other Asian and European countries (Lee, 1994; King et al., 2008). Grafting is a popular technique in watermelon and melon production in Turkey. Although commercial growing of eggplant is constrained due to soil-borne pathogens, such as Verticillium dahliae and Meloidogyne incognita (root-knot nematode) (Elekçioğlu et al., 1994), grafting is not yet common even in protected cultivation. Grafting on rootstocks with multiple pathogen resistance may be used intensively in protected cultivation and in organic farming in Turkey in the near future.

The most common rootstocks for eggplant are tomato (Ioannou, 2001) and wild-related species such as Solanum torvum Sw., Solanum integrifolium Poir. and Solanum sisymbriifolium Lam. (Lee, 1994; Bletsos et al., 2003). S. torvum was reported to be resistant to Verticillium and bacterial wilt, root-knot nematode and mycoplasma (Collonnier et al., 2001; Kashyap et al., 2003). However, it was found that $20-27 \%$ of S. torvum plants and $87-100 \%$ of eggplants showed symptoms caused by different isolates of $V$. dahliae Kleb. isolated in Italy (Garibaldi et al., 2005). Bletsos et al. (2003) reported that grafting of eggplant onto S. torvum and S. sisymbriifolium had positive effects on plant growth, yield and disease incidence of $V$. dahliae with no change in fruit quality, and that $S$. torvum was more resistant than $S$. sisymbriifolium to Verticillium wilt. Although there are many conflicting reports on changes in fruit quality resulting from grafting in vegetables (Davis et al., 2008), little literature is available related to the effect of Solanum rootstocks on yield, growth and fruit quality in noninfested (Çürük et al., 2005; Passam et al., 2005) and infested soil with only Verticillium wilt (Bletsos et al. 2003; Bletsos, 2006) under protected cultivation. Sometimes, multiple pathogens infect the crops simultaneously. Several cases have been reported for root-knot/lesion nematodes in breaking down the resistance of tomato, eggplant, cotton and peppermint plants to Fusarium/ Verticillium wilt disease due to increasing severity of the disease (Hasan \& Khan, 1985; Katsantonis et al., 2003). Therefore, yield, growth and fruit quality of eggplant, grafted on $S$. torvum, might be significantly affected in soil infested with two different pathogens that have synergic effect. It was found that grafted eggplants on tomato rootstock showed promising results for control of multiple pathogens (Ioannou, 2001). However, there is no information concerning the effect of $S$. torvum rootstock on yield, fruit quality and growth, in infested soil with two pathogens, such as Verticillium wilt and root-knot nematode that have synergic effect and, sometimes, simultaneously infect the eggplant and other crops (Hasan \& Khan, 1985).

The objective of this study was to investigate the effect of grafting (onto $S$. torvum) on plant growth, yield and fruit quality of the Faselis and Pala eggplant cultivars, that are popular in protected and field eggplant cultivation, respectively, in Turkey, in noninfested and infested soils with $V$. dahliae Kleb. and $M$. incognita.

\section{Materials and Methods}

The experiments were carried out in the 2003/2004 and 2004/2005 growing periods, in an unheated glasshouse at the Agricultural Research Station of Mustafa Kemal University, Antakya, in southeastern Mediterranean region of Turkey. The study area is in the Amik plain at $36^{\circ} 19^{\prime} \mathrm{N}$ and $36^{\circ} 11^{\prime} \mathrm{E}$, at $100-\mathrm{m}$ altitude. Total annual rainfall was $1,155 \mathrm{~mm}$ in $2003 / 2004$ and $750 \mathrm{~mm}$ in 2004/2005. No rain occurred in June and July, during the first cropping period. Average maximum, minimum and mean air temperatures were about $21^{\circ} \mathrm{C}, 12.5^{\circ} \mathrm{C}$ and $16.2-17^{\circ} \mathrm{C}$, respectively, for the cropping periods in both years. The mean relative humidity was ca. 69 and 67\%, during the 2003/2004 and 2004/2005 growing periods, respectively. The greenhouse used was a glasshouse with steel structure, with a $12.8-\mathrm{m}$ width span, $2.5-\mathrm{m}$ gutter height, $4.5-\mathrm{m}$ ridge height, continuous roof $(1 \mathrm{~m})$ and side $(1.2 \mathrm{~m})$ ventilation windows. In the glasshouse, average maximum, minimum and mean air temperatures and relative humidities were $32.515 .3,22.6^{\circ} \mathrm{C}$, and 95.8 , $47.22,74.5 \%$, respectively. Soil used as growing medium had the following attributes: sand $\left(490 \mathrm{~g} \mathrm{~kg}^{-1}\right)$; clay (270 $\left.\mathrm{g} \mathrm{kg}^{-1}\right)$; loam (240 $\left.\mathrm{g} \mathrm{kg}^{-1}\right)$ mixture; $\mathrm{pH}, 7.49$; electric conductivity, $1.58 \mathrm{~S} \mathrm{~m}^{-1}$; cation exchangeable 
capacity of $26.3 \mathrm{cmol}_{\mathrm{c}} \mathrm{kg}^{-1} ; \mathrm{CaCO}_{3}, 87 \mathrm{~g} \mathrm{~kg}^{-1} ; \mathrm{N}$, $360 \mathrm{~kg} \mathrm{ha}^{-1} ; \mathrm{P}_{2} \mathrm{O}_{5}, 18.3 \mathrm{~kg} \mathrm{ha}^{-1} ; \mathrm{K}_{2} \mathrm{O}, 514 \mathrm{mg} \mathrm{kg}^{-1}$. The soil was disinfested by solarization for 6 weeks (from August 23 to October 10). During solarization, soil was covered with transparent polyethylene film $(0.11 \mathrm{~mm})$ in a glasshouse and irrigated twice. Daily range of minimum and maximum temperature of the soil during solarization was $30-35$ and $40-45^{\circ} \mathrm{C}$, respectively.

The experimental design consisted of a randomized complete block factorial design in a split plot arrangement, with three replicates per treatment. The pathogen treatment (noninfested or infested soil with Verticillium wilt and root-knot nematode) was assigned to the main plots of each block, and cultivar (Pala or Faselis $\mathrm{F}_{1}$ ) and grafting (grafted on S. torvum or not grafted) combinations were assigned to the subplots of each main plot at random. Based on soil analysis, the total amount of applied $\mathrm{N}-\mathrm{P}_{2} \mathrm{O}_{5}-\mathrm{K}_{2} \mathrm{O}$ was 980-260-1,560 kg ha-1 (Paterson, 1989). All the manure and the fertilizer applied before planting were immediately incorporated into the soil. The fertilizer applied after planting was dissolved in water before using. Grafting by the budding method was used to produce grafted eggplant plantlets, since preliminary results showed that bud grafting method was more successful than tongue approach grafting. In the last week of April, the buds from 75-day old eggplant cultivars were grafted onto rooted cuttings of $S$. torvum by the budding method and placed under low plastic tunnels $(80-\mathrm{cm}$ wide $\mathrm{x} 60$-cm height) in the glasshouse. Three days after grafting, the cuttings were misted ( $30 \mathrm{~s}$, one time every $30 \mathrm{~min}$ ) for three weeks. Seeds of cultivars Faselis $F_{1}$ (De Ruiter Seeds, Holland) and Pala (an open-pollinated cultivar, Atatürk Central Horticultural Research Institute, Turkey) were sown in a sterile substrate composed of $50 \%$ of peat and perlite, in August of 2003 and 2004. Ungrafted control and grafted transplants with 5-6 leaves were transplanted to the plastic bags containing $25 \mathrm{~L}$ of soil mentioned above. Transplanting was carried out on $15^{\text {th }}$ and $22^{\text {nd }}$ of October in 2003 and 2004, respectively, at a density of $0.75 \times 0.5 \mathrm{~m}$. Grafted and control seedlings had similar plant length and leaf number at this stage. Unless otherwise noted, measurements were made on five plants in each replicate.

Verticillium dahliae EgVd3 isolates, obtained from diseased eggplant, and M. incognita were inoculated about two and four weeks after transplanting, respectively. Inoculations for Verticillium were carried out using the pipette inoculation method. The conidial suspension was adjusted to a concentration of $10^{6}$ conidia $\mathrm{mL}^{-1}$ with a hemacytometer. For pathogen inoculation, the conidial suspension $(250 \mathrm{~mL})$ was delivered to the substrate, around each seedling, using a micropipette. Control plants were similarly treated with sterile distilled water. Egg masses of M. incognita were collected from the galls of infected roots of eggplant. Each plant used in the infested plot was infected with 1,200 eggs of the nematode by placing the eggs into a hole of $5 \mathrm{~cm}$ depth near the roots. The plants were gently irrigated before and after inoculation, and the soil was kept wet to hatch the nematodes. The Verticillium wilt development in the individual plants was scored on a scale of 0 to 4 (Wilhelm et al., 1974) ten weeks after inoculation. A leaf symptom index (LSI) was used to evaluate symptom expressions in plants for Verticillium wilt resistance. At the end of the growing season, the main stem of each plant was cut approximately $5 \mathrm{~cm}$ above the graft union. Based on vascular discoloration, disease severity in the individual plants was rated on a scale of 0 to 5 (Xiao \& Subbarao, 1998). According to these values, a vascular discoloration index (VDI) was used to estimate the severity of vascular bundles discoloration. Finally, the disease index (DI) was calculated as the product of the two indices (LSI $x$ VDI), as proposed by Bletsos (2006).

Early fruit yield (from January to the end of April) and total yield (from January to the $15^{\text {th }}$ of July) of the eggplant (grams per plant) were taken from each plot and weighted on a weekly basis. Weights from each plot for each week were tallied, analyzed and presented as total average in grams per plant. Mean fruit weight (g) was calculated by dividing total fruit weight by the number of fruit. The eggplant fruit quality properties, namely $\mathrm{pH}$, basal (near the bottom) flesh firmness (Newton force), oxalic acid (\%) and total soluble solid ( ${ }^{\circ}$ Brix) were measured at least three times during the harvesting period. Measurement of fruit $\mathrm{pH}$ was made using a digital $\mathrm{pH}$ meter (HANNA instruments, 161 Kallang Way, Singapore, Singapore), and total soluble solids were measured in a few drops of the fruit juice using a hand refractometer (N.O.W. model no: 507-I, Tokyo, Japan). Flesh firmness was measured after the removal of $1 \mathrm{~mm}$ thick disk of fruit skin, and the force in kilograms required to insert an Effegi penetrometer (model FT 327, Wagner 
instruments Greenwich, CT, USA) fitted with an $8 \mathrm{~mm}$ diameter probe was recorded and converted to Newton $(\mathrm{N})$. Plant height $(\mathrm{cm})$, main stem diameter $1-2 \mathrm{~cm}$ above the graft union ( $\mathrm{mm})$, specific leaf area $\left(\mathrm{cm}^{2} \mathrm{~g}^{-1}\right)$, final leaf area $\left(\mathrm{cm}^{2}\right)$, final shoot dry weight $(\mathrm{g})$, harvest index (total fruit fresh weight divided by final shoot dry weight) and final above-ground total biomass (stem, leaf and fruit) (g) were recorded at the end of both cropping years. From each replicate, two plants were used for the measurements of specific leaf area, final leaf area, final shoot dry weight and final above-ground total biomass. Leaf area was calculated by weighing all leaves of a plant and determining specific leaf area $\left(\mathrm{cm}^{2} \mathrm{~g}^{-1}\right.$ fresh weight) of foliar subsamples (by leaf area meter MK2, Eijkelkamp, Holland). Specific leaf area was calculated by dividing leaf area of a foliar sample by leaf fresh weight of the sample of each plant. For determining shoot dry weight (grams per plant) at flowering, stems of the plants were cut about $5 \mathrm{~cm}$ above the graft union, at the end of the second cropping period. All the flowered, shoots, above the graft union, of two plants from each replicate were weighted after drying at $65^{\circ} \mathrm{C}$ for 3 days.

Statistical analyzes were done by using SAS (SAS Institute, 1999) and MSTAT-C (Freed \& Eisensmith, 1989). When year or interactions involving year were not significant, average data of the two cropping years were analyzed by a general linear model (GLM) ANOVA, and means were showed. When year and any interaction involving year were significant, data of each year were analyzed and showed separately. Duncan's multiple range test was conducted for pairwise comparisons.

\section{Results and Discussion}

The variables leaf symptom index, disease index, shoot dry weight at flowering, final shoot dry weight, fruit mean weight, plant stem diameter, plant height, final leaf area, final above-ground total biomass, early yield, total yield and oxalic acid were not significantly affected by year or interactions involving year. Therefore, the average data of the two years were presented for these variables. Harvest index was affected by year and year-treatment interactions, but when data were analyzed separately for both years, similar results were obtained. Thus, only the values of the second production year were presented.
The results of leaf symptom and disease index showed that the solarization and infestation (of the solarized soil) were successful, since the ungrafted eggplants showed the disease symptoms in the soil infested with Verticillium wilt and root-knot nematode, while those plants grown in noninfested soil did not show any symptom (Table 1). Leaf symptom index and disease index were significantly affected by pathogen, grafting, cultivar, pathogen-grafting and pathogen-cultivar interactions. In the infested soil, grafting significantly reduced the average leaf symptom and disease index by 51 and $43 \%$, respectively. This result is consistent with the reports by Ioannou (2001), Bletsos et al. (2003), Garibaldi et al. (2005) and Bletsos (2006). There was no significant difference between Pala and Faselis grown in noninfested soil; however, Pala was more resistant to the pathogens than Faselis in infested soil.

The effects of pathogen, cultivar and pathogen-grafting interaction on shoot dry weight at flowering were significant. Though the difference in shoot dry weight at flowering of grafted plants - grown in infested or noninfested soil - was not significant, there was a $58 \%$ reduction in dry weight of the ungrafted plants grown in infested compared to ones in noninfested soil (Table 1). It was reported that infection by $V$. dahliae reduced the dry weight of the eggplant shoot by $35 \%$ (Karagiannidis et al., 2002). Rouphael et al. (2008) reported that there was no significant difference in shoot dry weight between

Table 1. Values of leaf symptom index, disease index and shoot dry weight at flowering of eggplant cultivars grown with or without rootstock, in noninfested or infested soil with Verticillium dahliae and Meloidogyne incognita ${ }^{(1)}$.

\begin{tabular}{|c|c|c|c|c|}
\hline $\begin{array}{l}\text { Pathogen/ } \\
\text { Cultivar }\end{array}$ & $\begin{array}{l}\text { Grafting/ } \\
\text { Cultivar }\end{array}$ & $\begin{array}{l}\text { Leaf symptom } \\
\text { index }\end{array}$ & $\begin{array}{l}\text { Disease } \\
\text { index }\end{array}$ & $\begin{array}{c}\text { Shoot dry weight } \\
\text { (g per plant) }\end{array}$ \\
\hline & & \multicolumn{3}{|c|}{ Pathogen x Grafting } \\
\hline \multirow[t]{2}{*}{ Noninfested } & Ungrafted & $0.000 \mathrm{c}$ & $0.000 \mathrm{c}$ & $17.18 \mathrm{a}$ \\
\hline & Grafted & $0.000 \mathrm{c}$ & $0.000 \mathrm{c}$ & $12.19 \mathrm{ab}$ \\
\hline \multirow[t]{2}{*}{ Infested } & Ungrafted & $2.000 \mathrm{a}$ & $3.333 \mathrm{a}$ & $7.18 \mathrm{~b}$ \\
\hline & Grafted & $0.983 b$ & $1.900 \mathrm{~b}$ & $11.13 \mathrm{ab}$ \\
\hline & & \multicolumn{3}{|c|}{ Pathogen x Cultivar } \\
\hline \multirow[t]{2}{*}{ Noninfested } & Pala & $0.000 \mathrm{c}$ & $0.000 \mathrm{c}$ & $19.98 \mathrm{a}$ \\
\hline & Faselis & $0.000 \mathrm{c}$ & $0.000 \mathrm{c}$ & $9.40 \mathrm{a}$ \\
\hline \multirow[t]{2}{*}{ Infested } & Pala & $1.217 \mathrm{~b}$ & $1.583 b$ & $12.28 \mathrm{a}$ \\
\hline & Faselis & $1.767 \mathrm{a}$ & $3.650 \mathrm{a}$ & $6.03 \mathrm{a}$ \\
\hline & & \multicolumn{3}{|c|}{ Pathogen } \\
\hline Noninfested & & $0.000 \mathrm{~b}$ & $0.000 \mathrm{~b}$ & $14.69 \mathrm{a}$ \\
\hline \multirow[t]{2}{*}{ Infested } & & $1.492 \mathrm{a}$ & $2.617 \mathrm{a}$ & $9.16 \mathrm{~b}$ \\
\hline & & \multicolumn{3}{|c|}{ Cultivar } \\
\hline Pala & & $0.608 \mathrm{~b}$ & $0.792 b$ & $16.13 \mathrm{a}$ \\
\hline Faselis & & $0.883 \mathrm{a}$ & $1.825 \mathrm{a}$ & $7.72 \mathrm{~b}$ \\
\hline $\mathrm{CV}(\%)$ & & 27.14 & 47.26 & 40.22 \\
\hline
\end{tabular}
differ by Duncan's multiple range test, at $5 \%$ probability. 
grafted and ungrafted cucumber plant. However, Fernandez-Garcia et al. (2004a) showed that shoot dry weight of grafted tomato plants was greater than of ungrafted ones. In our study, mean shoot dry weight at flowering of Pala was 52\% greater than that of Faselis (Table 1). The effect of grafting on final shoot dry weight differed between the cultivars (Table 2). Final shoot dry weight of Pala increased $26 \%$ by grafting, but was not significantly different in Faselis. Rouphael et al. (2008) reported that there was no significant difference between grafted and ungrafted cucumber plant concerning shoot dry weight. However, Fernandez-Garcia et al. (2004a) showed that shoot dry weight of grafted tomato plants was greater than that of ungrafted ones.

The mean weight of fruit was significantly affected by grafting, cultivar, pathogen-cultivar and grafting-cultivar interactions. When Faselis was grafted on $S$. torvum, mean fruit weight increased by $20 \%$, but this did not when Pala was grafted (Table 2). There are reports which indicate

Table 2. Value of final shoot dry weight, fruit mean weight, plant stem diameter and plant height of eggplant cultivars grown with or without rootstock, in noninfested or infested soil with Verticillium dahliae and Meloidogyne incognita ${ }^{(1)}$.

\begin{tabular}{|c|c|c|c|c|c|}
\hline $\begin{array}{l}\text { Grafting/ } \\
\text { Pathogen }\end{array}$ & Cultivar & $\begin{array}{l}\text { Final shoot } \\
\text { dry weight } \\
\text { (g per plant) }\end{array}$ & $\begin{array}{c}\text { Fruit mean } \\
\text { weight } \\
\text { (g) }\end{array}$ & $\begin{array}{c}\text { Plant stem } \\
\text { diameter } \\
(\mathrm{mm})\end{array}$ & $\begin{array}{l}\text { Plant } \\
\text { height } \\
(\mathrm{cm})\end{array}$ \\
\hline & & \multicolumn{4}{|c|}{ Grafting $\mathrm{x}$ cultivar } \\
\hline \multirow[t]{2}{*}{ Ungrafted } & Pala & $370.9 b$ & $99.0 \mathrm{c}$ & $26.15 b$ & $159 \mathrm{~b}$ \\
\hline & Faselis & $145.4 \mathrm{c}$ & $113.1 \mathrm{~b}$ & $18.19 \mathrm{c}$ & $143 c$ \\
\hline \multirow[t]{3}{*}{ Grafted } & Pala & $467.0 \mathrm{a}$ & $104.9 \mathrm{c}$ & $40.15 a$ & $174 \mathrm{a}$ \\
\hline & Faselis & $138.1 \mathrm{c}$ & $135.8 \mathrm{a}$ & $27.89 \mathrm{~b}$ & $127 \mathrm{~d}$ \\
\hline & & \multicolumn{4}{|c|}{ Pathogen $\mathrm{x}$ cultivar } \\
\hline \multirow[t]{2}{*}{ Noninfested } & Pala & $426.6 \mathrm{a}$ & $99.8 \mathrm{c}$ & $34.59 \mathrm{a}$ & $174 \mathrm{a}$ \\
\hline & Faselis & $153.2 \mathrm{a}$ & $128.1 \mathrm{a}$ & $23.65 \mathrm{a}$ & $143 a$ \\
\hline \multirow[t]{3}{*}{ Infested } & Pala & $411.2 \mathrm{a}$ & $104.2 \mathrm{c}$ & $31.71 \mathrm{a}$ & $158 \mathrm{a}$ \\
\hline & Faselis & $130.3 \mathrm{a}$ & $120.9 b$ & $22.43 \mathrm{a}$ & $127 \mathrm{a}$ \\
\hline & & \multicolumn{4}{|c|}{ Pathogen } \\
\hline Noninfested & & $289.9 \mathrm{a}$ & $113.9 \mathrm{a}$ & $29.12 \mathrm{a}$ & $158 \mathrm{a}$ \\
\hline Infested & & $270.7 \mathrm{a}$ & $112.5 \mathrm{a}$ & $27.07 \mathrm{a}$ & $143 b$ \\
\hline $\mathrm{CV}(\%)$ & & 20.38 & 5.69 & 6.91 & 4.91 \\
\hline
\end{tabular}

${ }^{(1)}$ Values of each parameter, followed by equal letters in the columns, do not differ by Duncan's multiple range test, at $5 \%$ probability. that grafting may increase fruit size in watermelon (Miguel et al., 2004) and eggplant (Bletsos et al., 2003; Passam et al., 2005). However, it was reported that grafting did not change average fruit weight of tomato (Fernandez-Garcia et al., 2004b). According to Crino et al. (2007), fruit size of melon differed relating to the type of rootstock (Cucumis melo or Cucurbita maxima $\mathrm{x}$ Cucurbita moschata) and cropping season. Mean weight of fruit in Faselis reduced significantly $(6 \%)$ by inoculating the soil with the pathogens but not in Pala.

There were significant effects of grafting, cultivar and grafting-cultivar interaction on stem diameter. Average stem diameter of the grafted plants of both cultivars were found to be $53 \%$ greater than of the controls, and the highest and the lowest average stem diameters were obtained from grafted Pala and ungrafted Faselis plants, respectively (Table 2). Bletsos et al. (2003) and Çürük et al. (2005) reported that stem diameter increased in scions of certain eggplant varieties grafted onto S. torvum. However, Leonardi \& Giuffrida (2006) found that the stem diameter of self-grafted eggplants was equal to or lower than that of eggplant grafted onto different tomato rootstocks.

Plant height was significantly affected by pathogen, cultivar and grafting-cultivar interaction. Soil infestation with the pathogens reduced plant height by $9.5 \%$ (Table 2). It was reported that infection by $V$. dahliae reduced plant height of eggplant by $12 \%$ (Karagiannidis et al., 2002). In our study, while plant height of Faselis reduced $11 \%$ by grafting, the height of Pala increased $10 \%$ (Table 2). This result is consistent with the findings of Çürük et al. (2005), Passam et al. (2005) and Leonardi \& Giuffrida (2006) indicating that the effect of grafting on plant height differed regarding the combination of rootstock/eggplants varieties used.

Final leaf area and harvest index were affected only by cultivar. Pala had a final leaf area $35 \%$ greater than that of Faselis (Table 3), wich corroborates Çürük et al.

Table 3. Mean values of final leaf area, harvest index, early yield, total yield and final above-ground total biomass of eggplant cultivars grown in noninfested or infested soil with Verticillium dahliae and Meloidogyne incognita ${ }^{(1)}$.

\begin{tabular}{|c|c|c|c|c|c|}
\hline Treatment & $\begin{array}{l}\text { Final leaf area } \\
\left(\mathrm{cm}^{2} \text { per plant }\right)\end{array}$ & $\begin{array}{c}\text { Harvest index } \\
\text { (fruit per shoot dry weight) }\end{array}$ & $\begin{array}{c}\text { Early yield } \\
\text { (g per plant) }\end{array}$ & $\begin{array}{l}\text { Total yield } \\
\text { (g per plant) }\end{array}$ & $\begin{array}{c}\text { Total biomass } \\
\text { (g per plant) }\end{array}$ \\
\hline \multicolumn{6}{|l|}{ Pathogen } \\
\hline Noninfested & $21,099 \mathrm{a}$ & $32.30 \mathrm{a}$ & $766 a$ & $5,200 \mathrm{a}$ & $6,739 a$ \\
\hline Infested & $18,536 \mathrm{a}$ & $32.16 \mathrm{a}$ & $582 \mathrm{~b}$ & $4,499 \mathrm{~b}$ & $5,825 \mathrm{~b}$ \\
\hline \multicolumn{6}{|l|}{ Cultivar } \\
\hline Pala & $24,009 \mathrm{a}$ & $12.77 b$ & $205 b$ & $4,327 b$ & $6,270 \mathrm{a}$ \\
\hline Faselis & $15,626 b$ & $51.68 \mathrm{a}$ & $1,143 \mathrm{a}$ & $5,732 \mathrm{a}$ & $6,294 \mathrm{a}$ \\
\hline CV (\%) & 2.10 & 15.44 & 22.29 & 14.22 & 9.92 \\
\hline
\end{tabular}

${ }^{(1)}$ Values of each parameter followed by equal letters in the columns, do not differ by Duncan's multiple range test, at $5 \%$ probability. 
(2005). It was found that the harvest index for Pala was only 25\% of that for Faselis (Table 3), showing that Pala is less productive than Faselis, with the dry weight increase of the shoot by grafting most likely going to leaf and stem instead of the fruit. Early and total fruit yield differed significantly with the cultivar and pathogen infestation. When the pathogens were applied, early and total yields were significantly reduced by 24 and $13 \%$, respectively. Compared to ungrafted control eggplants grown in noninfested soil, the yield reduction in total fruit production caused by infestation was 7 and $14 \%$ for grafted and ungrafted eggplants, respectively, but these decrements were not statistically significant. Leonardi \& Giuffrida (2006) have showed that yields of eggplants grafted on tomato rootstock cultivars such as PG3, Energy and Beaufort (interspecific hybrid) were significantly lower than those of self-grafted ones in a noninfested soil. However, an opposite result was reported by Passam et al. (2005), stating that yield of grafted eggplant onto certain tomato rootstock was greater than the yield of the ungrafted control or grafted onto $S$. melongena rootstocks. Average early yield in Faselis was 5.5 times that of Pala. However, total yield in Faselis was only 1.2 of Pala. This showed that Faselis has advantage of earliness. The final above-ground total biomass was affected significantly by pathogen infestation. Soil infestation decreased average final total biomass by $14 \%$. It was reported that infection by $V$. dahliae reduced fresh weight of the eggplant shoot by $27 \%$ (Karagiannidis et al., 2002).

Oxalic acid content of fruit differed significantly depending on the pathogen, grafting and cultivar (Table 4). Soil infestation decreased oxalic acid content

Table 4. Mean values of oxalic acid (Average of 2003/2004 and 2004/2005) and soluble solid (2004/2005) of eggplant cultivars grown with or without rootstock, in noninfested or infested soil with Verticillium dahliae and Meloidogyne incognita $^{(1)}$.

\begin{tabular}{lcc}
\hline Treatment & Oxalic acid $(\%)$ & Soluble solid $\left({ }^{\circ}\right.$ Brix $)$ \\
\hline Pathogen & & \\
Noninfested & $0.1056 \mathrm{a}$ & $4.922 \mathrm{a}$ \\
Infested & $0.1004 \mathrm{~b}$ & $4.681 \mathrm{~b}$ \\
\hline Cultivar & $0.1134 \mathrm{a}$ & $5.222 \mathrm{a}$ \\
Pala & $0.0926 \mathrm{~b}$ & $4.381 \mathrm{~b}$ \\
Faselis & $0.1080 \mathrm{a}$ & \\
Grafting & $0.0980 \mathrm{~b}$ & $5.003 \mathrm{a}$ \\
Ungrafted & 5.45 & $4.600 \mathrm{~b}$ \\
Grafted & CV $(\%)$ & 3.30
\end{tabular}

(1)Values of each parameter followed by equal letters in the columns, do not differ by Duncan's multiple range test at $5 \%$ probability. by $5 \%$. The average oxalic acid content of Faselis was $18 \%$ lower than that of Pala. Grafting resulted in a significant reduction (9\%) in average oxalic acid content in both cultivars. This result is consistent with the report of Çürük et al. (2005). Oxalic acid and its salts occur as an end product of metabolism in a number of plant tissues. When plants are eaten they may have an adverse effect because oxalates bind calcium and other minerals (Noonan \& Savage, 1999). Our results showed that grafting in eggplants may improve the fruit quality by reducing the amount of the oxalic acid in the fruit.

Since the variables soluble solid, specific leaf area, fruit $\mathrm{pH}$ and basal flesh firmness were affected by the year and its interactions, the data of each year were presented separately. Concerning soluble solid content, grafting, cultivar, pathogen-grafting and grafting-cultivar interactions were significant in 2003/2004 (Table 5). However, only pathogen, grafting and cultivar were significant in 2004/2005 (Table 4). Soluble solid content of Pala was greater than that of Faselis in both years (Table 4 and 5). In 2004/2005, soluble solid content decreased 5 and $8 \%$ by pathogen infestation and grafting, respectively (Table 4). In 2003/2004, however, grafting reduced soluble solid content in Faselis in noninfested soil (Table 5). Soluble solid content of fruit was reported to decrease in tomato, cucumber and eggplant due to grafting (Çürük et al., 2005; Davis et al., 2008). However, negative, positive or no effect of grafting on soluble solid content was also reported in melon and watermelon (Nisini et al., 2002; Miguel et al., 2004; Davis et al., 2008). Specific leaf area was affected significantly by grafting in infested soil, in 2003/2004, and by pathogen-grafting interaction in both years. In infested soil, grafting significantly reduced specific leaf area in 2003/2004, but the difference between grafted and ungrafted plants in 2004/2005 was not significant (Table 5). It was shown that specific leaf area was not affected by grafting in cucumber (Rouphael et al., 2008). Fruit $\mathrm{pH}$ was found to be affected significantly by cultivar, pathogen-cultivar and pathogen-grafting-cultivar interactions in 2003/2004 (Table 6), and by cultivar and grafting-cultivar interactions in 2004/2005. In 2004/2005, grafting increased fruit $\mathrm{pH}$ in Faselis, but not in Pala (Table 5). In 2003/2004, the highest fruit $\mathrm{pH}$ was obtained from grafted Pala and the lowest one from grafted Faselis in noninfested soil (Table 6). It was reported by Çürük et al. (2005) and Davis et al. (2008) 
Table 5. Mean values of soluble solid, specific leaf area and fruit pH of eggplant cultivars grown with or without rootstock, in noninfested or infested soil with Verticillium dahliae and Meloidogyne incognita ${ }^{(1)}$.

\begin{tabular}{|c|c|c|c|c|c|}
\hline \multirow[t]{2}{*}{ Grafting } & \multirow[t]{2}{*}{ Cultivar/Pathogen } & \multirow{2}{*}{$\begin{array}{c}\text { Soluble solid }\left({ }^{\circ} \text { Brix }\right) \\
2003 / 2004\end{array}$} & \multicolumn{2}{|c|}{ Specific leaf area $\left(\mathrm{cm}^{2} \mathrm{~g}^{-1}\right.$ fresh weight $)$} & \multirow{2}{*}{$\frac{\text { Fruit pH }}{2004 / 2005}$} \\
\hline & & & $2003 / 2004$ & $2004 / 2005$ & \\
\hline & & \multicolumn{4}{|c|}{ Grafting $\mathrm{x}$ cultivar } \\
\hline \multirow[t]{2}{*}{ Ungrafted } & Pala & $5.750 \mathrm{a}$ & $31.24 \mathrm{a}$ & $29.94 \mathrm{a}$ & $5.597 \mathrm{a}$ \\
\hline & Faselis & $5.133 b$ & $34.76 \mathrm{a}$ & $32.43 \mathrm{a}$ & $5.457 \mathrm{c}$ \\
\hline \multirow[t]{3}{*}{ Grafted } & Pala & $5.589 \mathrm{a}$ & $30.25 a$ & $30.94 a$ & $5.580 \mathrm{a}$ \\
\hline & Faselis & $4.511 \mathrm{c}$ & $32.43 \mathrm{a}$ & $31.63 \mathrm{a}$ & $5.521 b$ \\
\hline & & \multicolumn{4}{|c|}{ Grafting $\mathrm{x}$ pathogen } \\
\hline \multirow[t]{2}{*}{ Ungrafted } & Noninfested & $5.539 \mathrm{a}$ & $31.67 \mathrm{~b}$ & $31.60 \mathrm{ab}$ & $5.522 \mathrm{a}$ \\
\hline & Infested & $5.344 \mathrm{ab}$ & $34.34 \mathrm{a}$ & $30.78 \mathrm{ab}$ & $5.532 \mathrm{a}$ \\
\hline \multirow[t]{2}{*}{ Grafted } & Noninfested & $4.889 \mathrm{c}$ & $31.40 \mathrm{~b}$ & $30.24 b$ & $5.553 \mathrm{a}$ \\
\hline & Infested & $5.211 \mathrm{~b}$ & $31.28 \mathrm{~b}$ & $32.34 \mathrm{a}$ & $5.548 \mathrm{a}$ \\
\hline CV (\%) & & 4.22 & 3.43 & 4.87 & 0.68 \\
\hline
\end{tabular}

${ }^{(1)}$ Values of each parameter, followed by equal letters in the columns, do not differ by Duncan's multiple range test, at $5 \%$ probability.

Table 6. Mean values obtained in 2003/2004 of fruit $\mathrm{pH}$ and down flesh firmness of eggplant cultivars grown with or without rootstock, in noninfested or infested soil with Verticillium dahliae and Meloidogyne incognita ${ }^{(1)}$.

\begin{tabular}{llllc}
\hline Pathogen & Grafting & Cultivar & Fruit $\mathrm{pH}$ & $\begin{array}{c}\text { Basal flesh } \\
\text { firmness (N) }\end{array}$ \\
\hline Noninfested & Ungrafted & Pala & $5.659 \mathrm{ab}$ & $37.03 \mathrm{~d}$ \\
& & Faselis & $5.593 \mathrm{~cd}$ & $45.44 \mathrm{a}$ \\
& Grafted & Pala & $5.672 \mathrm{a}$ & $37.23 \mathrm{~cd}$ \\
& Faselis & $5.531 \mathrm{e}$ & $40.67 \mathrm{bc}$ \\
Infested & Ungrafted & Pala & $5.628 \mathrm{abc}$ & $41.52 \mathrm{~b}$ \\
& & Faselis & $5.562 \mathrm{bc}$ & $45.89 \mathrm{a}$ \\
& \multirow{2}{*}{ Grafted } & Pala & $5.600 \mathrm{~cd}$ & $38.37 \mathrm{bcd}$ \\
& & Faselis & $5.559 \mathrm{de}$ & $47.82 \mathrm{a}$ \\
\hline CV (\%) & & & 0.44 & 4.48 \\
\hline
\end{tabular}

${ }^{(1)}$ Values of each parameter, followed by equal letters in the columns, do not differ by Duncan's multiple range test, at $5 \%$ probability.

that in eggplants plants grown in noninfested soil, the fruit $\mathrm{pH}$ was not significantly affected by grafting. It was shown that $\mathrm{pH}$ of the fruit of grafted melons was lower than that of ungrafted ones (Colla et al., 2006). The effects of cultivar and pathogen-grafting-cultivar interaction on basal flesh firmness were significant in 2003/2004, but were not significant in 2004/2005. Concerning pathogen-grafting-cultivar interactions in 2003/2004, the lowest and greatest basal flesh firmness were obtained from ungrafted Pala plants in noninfested soil and from pathogen-grafting-Faselis combinations, respectively (Table 6). There are many conflicting reports on the changes in firmness resulting from grafting in vegetables (Davis et al., 2008).

In general, infestation of the soil with the pathogens reduced fruit quality by decreasing mean weight and soluble solid content of the fruit depending on cultivar and year, respectively. Grafting reduced soluble solid content of the fruit in Faselis. However, it improved some of the fruit quality parameters by increasing mean fruit weight in Faselis and by reducing oxalic acid content in both cultivars. Therefore, grafting had positive effects on fruit quality in infested soil with two pathogens. It seems that the effects of grafted material on fruit quality are scion/rootstock specific. For example, fruit quality due to grafting was reported as unaffected in some studies (Nisini et al., 2002; Bletsos et al., 2003) and as having negative effect in others (Lee, 1994; Nisini et al., 2002). Contrasting results have been reported in eggplant (Bletsos et al., 2003).

Our findings show that vegetative growth and yield of grafted eggplant were affected by cultivar characteristics, as supported by Çürük et al. (2005). Differences in growth and yield could be attributed to the different growth characteristics of the cultivars (Pala is more vigorous and less fruit productive than Faselis), and to their different graft affinity and compatibility with the rootstock. S. torvum is a vigorous rootstock, and a graft combination of a vigorous cultivar with an equally vigorous rootstock reduces the amount of fertilizer required for the same yield (Suzuki \& Morishita, 2002). However, our results showed that the combination of a vigorous rootstock ( $S$. torvum) with a weak cultivar (Faselis) is more profitable than a vigorous rootstock (S. torvum) with a vigorous cultivar (Pala). 


\section{Conclusions}

1. Use of $S$. torvum as a rootstock for eggplant cultivar Faselis, under the conditions of an unheated glasshouse in a soil infested with both $V$. dahliae and M. incognita, result in increased protection against pathogen infestations with less loss of quality and yield.

2. Vegetative growth, yield and fruit quality are affected by eggplant cultivar characteristics, and the combination of vigorous rootstock with weak cultivar is more profitable than that of vigorous rootstock and vigorous cultivar.

\section{Acknowledgements}

To Mustafa Kemal University (Turkey), for funding the project; To Dr. Yahya Kemal Avşar, for his critical reading of the manuscript.

\section{References}

BLETSOS, F.A. Grafting and calcium cyanamide as alternatives to methyl bromide for greenhouse eggplant production. Scientia Horticulturae, v.107, p.325-331, 2006.

BLETSOS, F.A.; THANASSOULOPOULOS, C.; ROUPAKIAS, D. Effect of grafting on growth, yield, and Verticillium wilt of eggplant. HortScience, v.38, p.183-186, 2003.

COLLA, G.; ROUPHAEL, Y.; CARDARELLI, M.; MASSA, D.; SALERNO, A.; REA, E. Yield, fruit quality and mineral composition of grafted melon plants grown under saline conditions. Journal of Horticultural Science and Biotechnology, v.81, p.146-152, 2006.

COLLONNIER, C.; FOCK, I.; KASHYAP, V.; ROTINO, G.L.; DAUNAY, M.C.; LIAN, Y.; MARISKA, I.K.; RAJAM, M.V.; SERVAES, A.; DUCREUX, G.; SIHACHAKR, D. Applications of biotechnology in eggplant. Plant Cell, Tissue and Organ Culture, v.65, p.91-107, 2001.

CRINO, P.; LO BIANCO, C.; ROUPHAEL, Y.; COLLA, G.; SACCARDO F.; PARATORE, A. Evaluation of rootstock resistance to fusarium wilt and gummy stem blight and effect on yield and quality of a grafted 'Inodorus' melon. HortScience, v.42, p.521-525, 2007.

ÇÜRÜK, S.; DURGAÇ, C.; ÖZDEMIR, B.; KURT, Ş. Comparisons of grafted biennial and conventional production systems for eggplant (Solanum melongena L.) varieties in a Mediterranean Region of Turkey. Asian Journal of Plant Sciences, v.2, p.117-122, 2005.

DAVIS, A.R.; PERKINS-VEAZIE, P.; HASSELL, R.; KING, S.R.; ZHANG, X. Grafting effects on vegetable quality. HortScience, v.43, p.1670-1672, 2008.
ELEKÇIOĞLU, I.H.; OHNESORGE, B.; LUNG, G.; UYGUN, N. Plant parasitic nematodes in the east Mediterranean region of Turkey. Nematologia Mediterranea, v.22, p.59-63, 1994.

FERNANDEZ-GARCIA, N.; MARTINEZ, V.; CARVAJAL, M. Effect of salinity on growth, mineral composition, and water relations of grafted tomato plants. Journal of Plant Nutrition and Soil Science, v.167, p.616-622, 2004a.

FERNANDEZ-GARCIA, N.; MARTINEZ, V.; CERDA A.; CARVAJAL, M. Fruit quality of grafted tomato plants grown under saline conditions. Journal of Horticultural Science and Biotechnology, v.79, p.995-1001, 2004b.

FREED, R.D.; EISENSMITH, S. MSTAT-C: a software package for the design, management, and analysis of agronomic experiments. East Lansing: Michigan State University, 1989.

GARIBALDI, A.; MINUTO A.; GULLINO, M.L. Verticillium wilt incited by Verticillium dahliae in eggplant grafted on Solanum torvum in Italy. Plant Disease, v.89, p.777, 2005.

HASAN, A.; KHAN, M.N. The effect of Rhizoctonia solani, Sclerotium rolfisii, and Verticillium dahlia on the resistance of tomato to Meloidogyne incognita. Nematologia Mediterranea, v.13, p.133-136, 1985.

IOANNOU, N. Integrating soil solarization with grafting on resistant rootstocks for management of soil-borne pathogens of eggplant. Journal of Horticultural Science and Biotechnology, v.76, p.396-401, 2001.

KARAGIANNIDIS, N.; BLETSOS F.; STAVROPOULOS, N. Effect of Verticillium wilt (Verticillium dahliae Kleb.) and mycorrhiza (Glomus mosseae) on root colonization, growth and nutrient uptake in tomato and eggplant seedlings. Scientia Horticulturae, v.94, p.145-156, 2002.

KASHYAP, V.; KUMAR, S.V.; COLLONNIER, C.; FUSARI, F.; HAICOUR, R.; ROTINO, G.L.; SIHACHAKR, D.; RAJAM, M.V. Biotechnology of eggplant. Scientia Horticulturae, v.97, p.1-25, 2003.

KATSANTONIS, D.; HILLOCKS, R.J.; GOWEN, S. Comparative effect of root-knot nematode on severity of Verticillium and Fusarium wilt in cotton. Phytoparasitica, v.31, p.154-162, 2003.

KING, S.R.; DAVIS, A.R.; LIU, W.G.; LEVI, A. Grafting for disease resistance. HortScience, v.43, p.1673-1676, 2008.

LEE, J.M. Cultivation of grafted vegetables. I. Current status, grafting methods, and benefits. HortScience, v.29, p.235-239, 1994.

LEONARDI, C.; GIUFFRIDA, F. Variation of plant growth and macronutrient uptake in grafted tomatoes and eggplants on three different rootstocks. European Journal of Horticultural Science, v.71, p.97-101, 2006.

MIGUEL, A.; MAROTO, J.V.; BAUTISTA, A.S.; BAIXAULI, C.; CEBOLLA, V.; PASCUAL, B.; LÓPEZ, S.; GUARDIOLA, J.L. The grafting of triploid watermelon is an advantageous alternative to soil fumigation by methyl bromide for control of Fusarium wilt. Scientia Horticulturae, v.103, p.9-17, 2004.

NISINI, P.T.; COLLA, G.; GRANATI, E.; TEMPERINI, O.; CRINO, P.; SACCARDO, F.; Rootstock resistance to fusarium wilt 
and effect on fruit yield and quality of two muskmelon cultivars. Scientia Horticulturae, v.93, p.281-288, 2002.

NOONAN, S.C.; SAVAGE, G.P. Oxalate content of foods and its effect on humans. Asia Pacific Journal of Clinical Nutrition, v.8, p.64-74, 1999.

PASSAM, H.C.; STYLIANOU, M.; KOTSIRAS, A. Performance of eggplant grafted on tomato and eggplant rootstocks. European Journal of Horticultural Science, v.70, p.130-134, 2005.

PATERSON, J.W. Eggplants. In: PLUCKNETT, D.L.; SPRAGUE, H.B. (Ed.). Detecting mineral nutrient deficiencies in tropical and temperate crops. Boulder: Westview, 1989. Cap. 25.

ROUPHAEL, Y.; CARDARELli, M.; REA, E.; COLLA, G. Grafting of cucumber as a means to minimize copper toxicity. Environmental and Experimental Botany, v.63, p.49-58, 2008.
SAS INSTITUTE. SAS OnlineDoc ${ }^{\circledR}$. Version 8. Cary: SAS Institute, 1999. Disponível em : <http://v8doc.sas.com/sashtml/>. Acesso em: 19 jan. 2010.

SUZUKI, T.; MORISHITA, M. Effects of scion and rootstock cultivars on growth and yield of eggplant cultured under two fertilizer levels. Journal of the Japanese Society for Horticultural Science, v.71, p.568-574, 2002.

WILHELM, S.; SAGEN, J.E.; TIETZ, H. Resistance to Verticillium wilt in cotton: sources, techniques of identification, inheritance trends, and the resistance potential of multiline cultivars. Phytopathology, v.64, p.924-931, 1974.

XIAO, C.L.; SUBBARAO, K.V. Relationships between Verticillium dahliae inoculum density and wilt incidence, severity, and growth of cauliflower. Phytopathology, v.88, p.1108-1115, 1998.

Received on September 20, 2009 and accepted on November 19, 2009 